Archive for

Organic Chemistry

Arkivoc 2020, part vii, 56-66

\title{
Asymmetric syntheses of potential anti-malarial drugs designed from Fieser's 2-hydroxy-3-(2-methyloctyl)naphthalene-1,4-dione
}

\author{
Louise M. Fisher, Eliana E. Kim, Nicolai V. Moskalev, and Gordon W. Gribble*
}

Department of Chemistry, Dartmouth College, Hanover, NH 03755, USA

Email: ggribble@dartmouth.edu

In celebration of the outstanding chemistry of Jan Bergman and for $\mathbf{5 0}$ years of his friendship and in memory of Bernard L. Trumpower

Received 03-30-2020

Accepted 04-28-2020

Published on line $05-08-2020$

\section{Abstract}

We describe asymmetric syntheses of the potential anti-malarial drugs (S)-2-(8-fluoro-2-methyloctyl)-3hydroxynaphthalene-1,4-dione, (S)-2-hydroxy-3-(8-trifluoromethyl-2-methyloctyl)-3-hydroxynaphthalene-1,4dione, and (S)-2-hydroxy-3-(2-methyloctyl)naphthalene-1,4-dione, which are patterned after Fieser's "10576," known to be active against the mosquito borne parasite Plasmodium falciparum.<smiles>[X]CCCCC[C@H](C)CC1=C(O)C(=O)c2ccccc2C1=O</smiles>

Keywords: Atovaquone, anti-malarials, asymmetric synthesis, 2-hydroxynaphthalene-1,4-dione 


\section{Introduction}

Malaria, a disease transmitted by the mosquito borne parasite Plasmodium falciparum, is generally considered to be the most serious infectious disease in the world. It has been estimated by some parasitologists that $50 \%$ of the human beings ever born were killed by this parasite. ${ }^{1}$ It currently kills more than 400,000 people annually, more than half of whom are children under the age of 5 in sub-Saharan Africa. ${ }^{2}$ Unfortunately, the malaria parasite, through mutations has become resistant to known drugs, including atovaquone (1), a 2hydroxynaphthalene-1,4-dione (2-hydroxy-1,4-naphthoquinone), which is an active component in Proguanil, a drug used to treat parasitic infections since the 1990s. ${ }^{3}$ Moreover, naphthoquinones, such as derivatives of lawsone (2), lapachol (3), and $\beta$-lapachone (4), and others, have been of great interest in recent years as possible new agents to treat parasitic, fungal, and other infections, including malaria (Figure 1). ${ }^{4-10}$

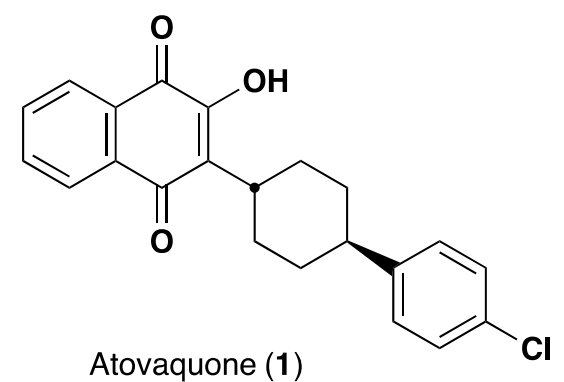

Atovaquone (1)

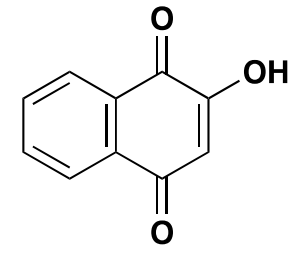

Lawsone (2)<smiles>CC(C)=CCC1=C(O)C(=O)c2ccccc2C1=O</smiles>

Lapachol (3)<smiles>CC1(C)CCC2=C(O1)c1ccccc1C(=O)C2=O</smiles>

$\beta$-Lapachone (4)

Figure 1. Structures of antimalarial naphthoquinones 1-4.

In connection with our interest in developing novel anti-malarial drugs based on lapachones and related 2-hydroxynaphthalene-1,4-diones ${ }^{11-13}$ as inhibitors of the cytochrome $b c_{1}$ complex, $^{14}$ which is a respiratory enzyme essential for the Plasmodium falciparum parasite, we prepared the atovaquone analogue (S)-2hydroxy-3-(2-methyloctyl)naphthalene-1,4-dione ("S-10576") (5), which was first synthesized and screened in 1948 by Fieser in racemic form ("M-285") and found to have curative action against malarial infections. ${ }^{15}$ Although $\mathbf{5}$ is more potent than atovaquone, it undergoes rapid metabolism in humans by bis-hydroxylation of the two terminal alkyl groups to give a 2-methylheptyl carboxylic acid side chain. ${ }^{16}$ To preclude this oxidative metabolism of $\mathbf{5}$, we synthesized the fluorinated analogues (S)-2-(8-fluoro-2-methyloctyl)-3-hydroxynaphthalene-1,4-dione (6) ${ }^{17}$ and (S)-2-hydroxy-3-(8,8,8-trifluoro-2-methyloctyl)naphthalene-1,4-dione ("NQ1") $(7)^{12,13}$ (Figure 2). The $S$ configuration was predicated by a protein modeling study of the interaction of 5 with the Rieske iron-sulfur protein. ${ }^{12}$ Both 6 and 7 are more active than atovaquone, and 7 strongly inhibits atovaquone-resistant Plasmodium falciparum sporozoites. The $\mathrm{IC}_{50}$ data against Plasmodium berghei are shown for 5 and 7 in Figure $2 .^{13}$ However, 7 exhibits significantly lower species selectivity than $\mathbf{5 .}^{12,13}$ Atovaquone has $\mathrm{IC}_{50}=19.7 \mathrm{nM}$, and 6 has not yet been tested. 
<smiles>CCCCCC[C@H](C)CC1=C(O)C(=O)c2ccccc2C1=O</smiles>

S-10576 (5) $\left(\mathrm{IC}_{50}=96.2 \mathrm{nM}\right)$<smiles>C[C@H](CCCCCCF)CC1=C(O)C(=O)c2ccccc2C1=O</smiles>

6<smiles>C[C@H](CCCCCC(F)(F)F)CC1=C(O)C(=O)c2ccccc2C1=O</smiles>

NQ1 (7) $\left(\mathrm{IC}_{50}=17.1 \mathrm{nM}\right)$

Figure 2. Structures of antimalarial naphthoquinones 5-7.

\section{Results and Discussion}

Our initial synthesis of $6^{17}$ involved the preparation of (S)-8-fluoro-2-methyloctanal (16) and subsequent condensation with 2-hydroxy-1,4-naphthoquinone (17) using our three-component reductive alkylation method, ${ }^{19}$ to afford 6 in excellent yield (Scheme 1). Thus, synthesis of the known 8-fluorooctanoic acid (11), ${ }^{18}$ acid chloride formation, and the Evans chiral auxiliary methodology ${ }^{20}$ with (S)-4-benzyl-2-oxazolidinone (12), and asymmetric C-2 methylation ${ }^{20-22}$ of 13, afforded 14 in good overall yield from 11 . Interestingly, ester formation from the commercially available 8-bromooctanoic acid (8) gave $\mathbf{9}$ as a mixture of bromide and iodide, which was converted into fluoride 10. Reduction of $\mathbf{1 4}$ and oxidation of alcohol $\mathbf{1 5}$ gave the desired (S)-8-fluoro-2-methyloctanal (16). ${ }^{17}$

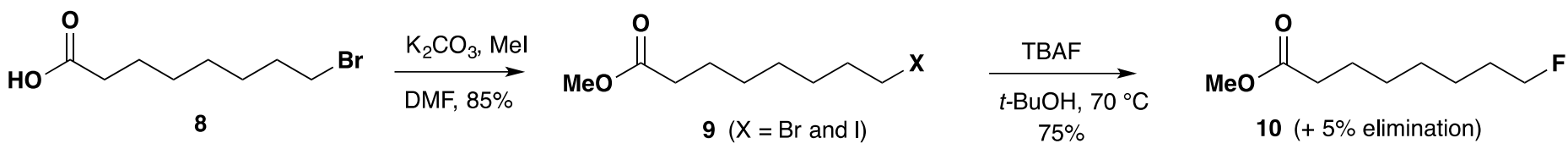<smiles>COC(OC)[C@H](OC)O[Na]</smiles>

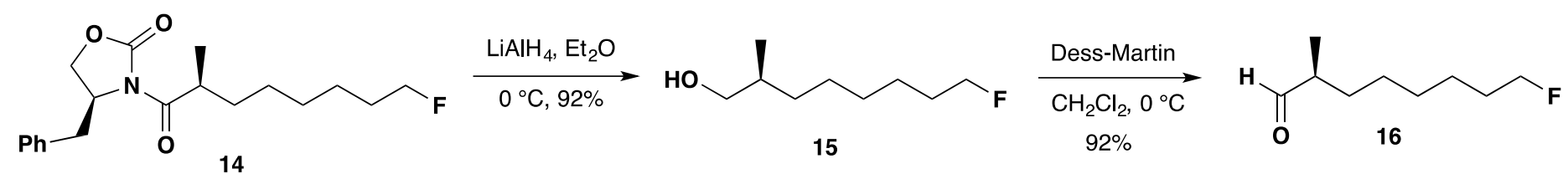<smiles>C[C@H](CCCCCCF)CC1=C(O)C(=O)c2ccccc2C1=O</smiles><smiles>CCOC(=O)C1=C(C)NC(C)=C(C(=O)OCC)C1</smiles><smiles>O=C1C=C(O)C(=O)c2ccccc21</smiles>

Scheme 1. Synthesis of (S)-2-(8-fluoro-2-methyloctyl)-3-hydroxynaphthalene-1,4-dione (6). ${ }^{17}$ 
We now describe an alternative synthesis of 6 via the new compounds (S)-8-bromo-2-methyloctanal (24) and (S)-2-(8-bromo-2-methyloctyl)-3-hydroxynaphthalene-1,4-dione (25) (Scheme 2), which avoids the intermediacy of the toxic octyl fluorides $\mathbf{1 0}$ and $\mathbf{1 1}$ (Krebs cycle poisons comparable to fluoroacetic acid). ${ }^{18}$ Furthermore, substitution of bromine should allow for further functionalization of this $\omega$-position. The chemistry follows that in Scheme 1 starting with 8-bromooctanoic acid (8) and affords $\mathbf{2 5}$ in good overall yield.

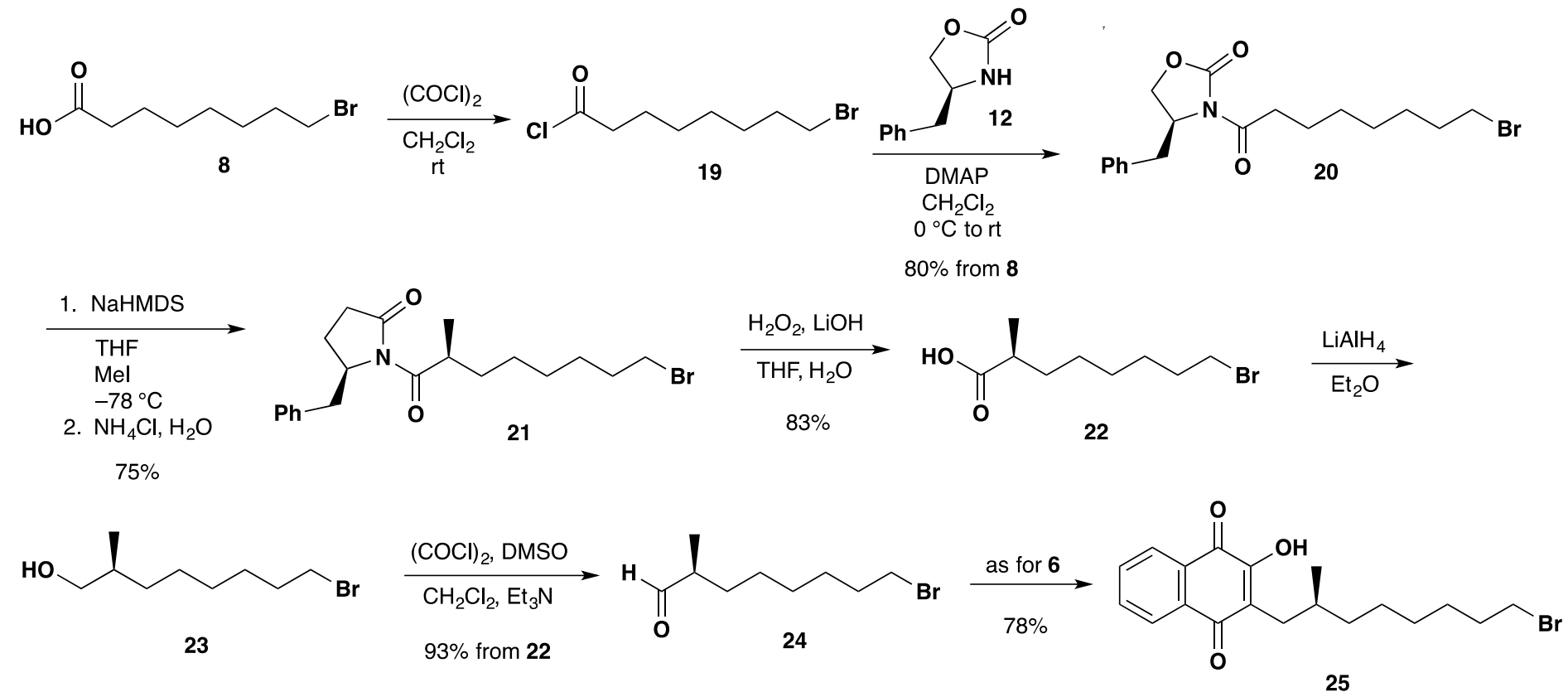

Scheme 2. Synthesis of (S)-2-(8-bromo-2-methyloctyl)-3-hydroxynaphthalene-1,4-dione (25).

Our syntheses of $\mathbf{5}$ and $\mathbf{7}$ take a different path from those of $\mathbf{6}$ and 25, and are described in Schemes 3 and 4 , respectively. In place of our three-component reductive alkylation of an aldehyde (i.e., $16+17+18$, Scheme 1), we employed tin-mediated coupling of the requisite alkyl iodide to 2-hydroxy-1,4-naphthalene-1,4dione sulfonate $\mathbf{3 0}$. The conversion of propanoate $\mathbf{2 6}$ to iodide $\mathbf{2 9}$ is known ${ }^{23}$ and sulfonate $\mathbf{3 0}$ was prepared from 2-hydroxy-1,4-naphthalene-1,4-dione (17) (using $\mathrm{PhSO}_{2} \mathrm{Cl}, \mathrm{K}_{2} \mathrm{CO}_{3}, \mathrm{DMF}, \mathrm{rt}$ ) in $78 \%$ yield. Whereas Fieser synthesized racemic 5 in 1948 ("10576"), our synthesis of (S)-5 is the first to be described of this biologically active stereoisomer (Scheme 3).

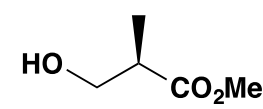

26

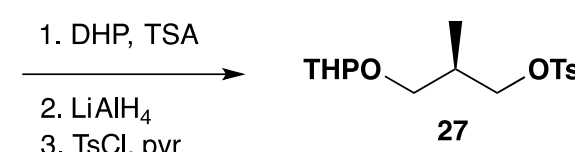

3. $\mathrm{TsCl}, \mathrm{pyr}$ $80 \%$

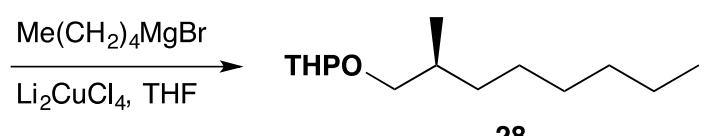

$90 \%$

28<smiles>CCCCCC[C@H](C)CC1=C(O)C(=O)c2ccccc2C1=O</smiles>

5 (S-10576)

Scheme 3. Synthesis of (S)-2-hydroxy-3-(2-methyloctyl)naphthalene-1,4-dione (5) (S-10576). 
Similar methodology was used to synthesize 7 (NQ1) (Scheme 4). ${ }^{11}$ Tosylate 27 was treated with Grignard 31, as prepared from 5-bromopentanoic acid in two steps with sulfur tetrafluoride ${ }^{24,25}$ and $\mathrm{Mg}$, to afford 32 in $50 \%$ yield. Conversion of $\mathbf{3 2}$ to iodide $\mathbf{3 3}$ and coupling with quinone sulfonate $\mathbf{3 0}$ gave the desired $\mathbf{7}$ (NQ1) in low yield. We prepared iodide $\mathbf{3 3}$ from $\mathbf{3 2}$ as we described in Scheme 3 for iodide 29.
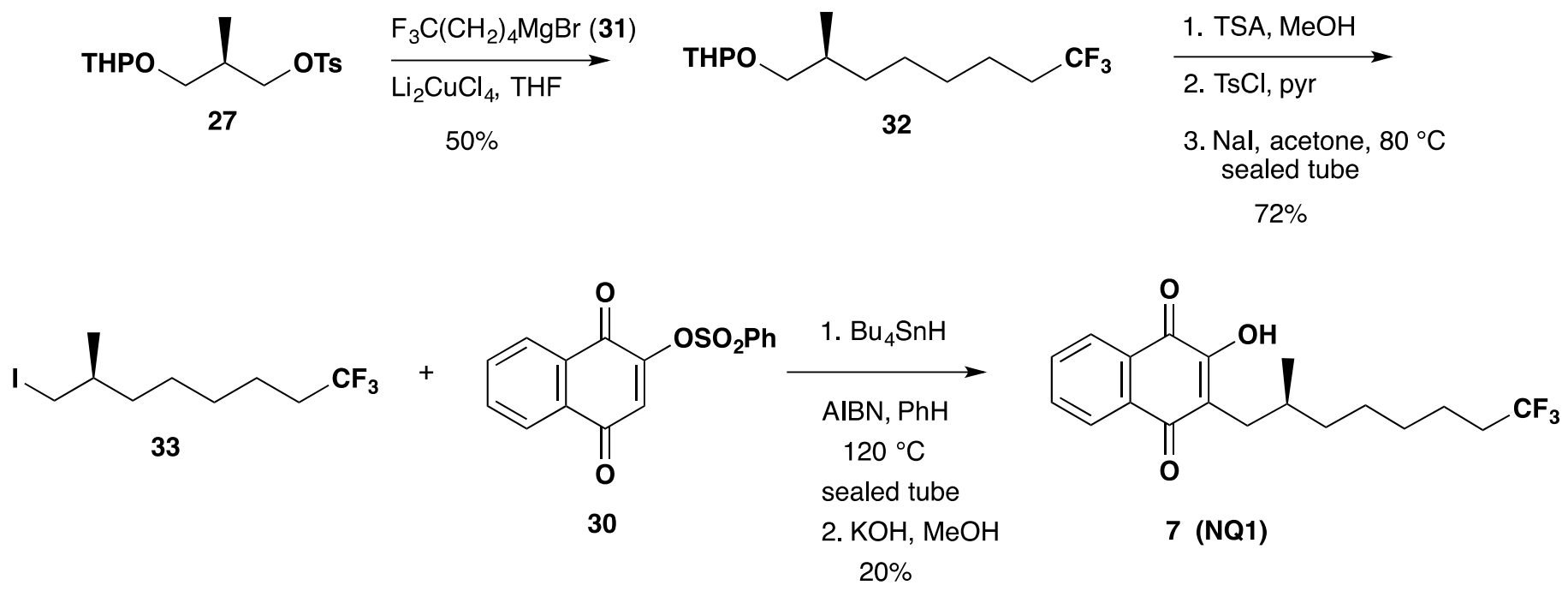

Scheme 4. Synthesis of (S)-2-hydroxy-3-(8,8,8-trifluoro-2-methyloctyl)naphthalene-1,4-dione (7) (NQ1).

Protein modeling studies suggested that the 8-methyl analogues might show improved activity, via noncovalent interactions between this methyl group and Cys-180 of the Rieske iron-sulfur protein and cytochrome $b$ in the ubiquinol oxidation pocket. ${ }^{11}$ We have prepared (S)-3-hydroxy-5-methyl-2-(8,8,8-trifluoro-2-methyloctyl)naphthalene-1,4-dione (39) (NQ3) ${ }^{11}$ using the tin coupling method shown in Schemes 3 and 4 . Thus, we synthesized 2-methoxy-8-methylnaphthalene-1,4-dione (37) from 2-methoxyhydroquinone (34) via known chemistry (oxidation, ${ }^{26,27}$ Diels-Alder cycloaddition, ${ }^{28}$ and aerial oxidation ${ }^{28}$ ) and coupled it with 33 as shown in Scheme 5. Demethylation with $\mathrm{BBr}_{3}{ }^{29}$ afforded 39 in low yield. Interestingly, the sulfonate corresponding to 38 could not be hydrolyzed with $\mathrm{KOH}$ to 39, in contrast to the results in Schemes 3 and 4. Disappointingly, analogue 39 (NQ3) shows much weaker activity against Plasmodium berghei ( $\left.\mathrm{IC}_{50}>4400 \mathrm{nM}\right)$ than we expected. ${ }^{13}$

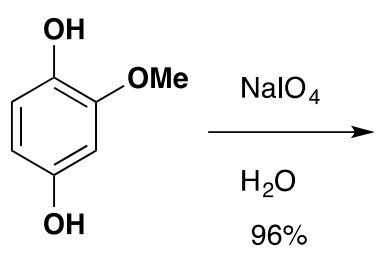

34

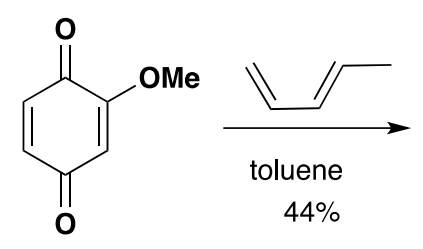

35<smiles>COC1=CC(=O)C2=C(C1=O)C(C)C=CC2</smiles>

36
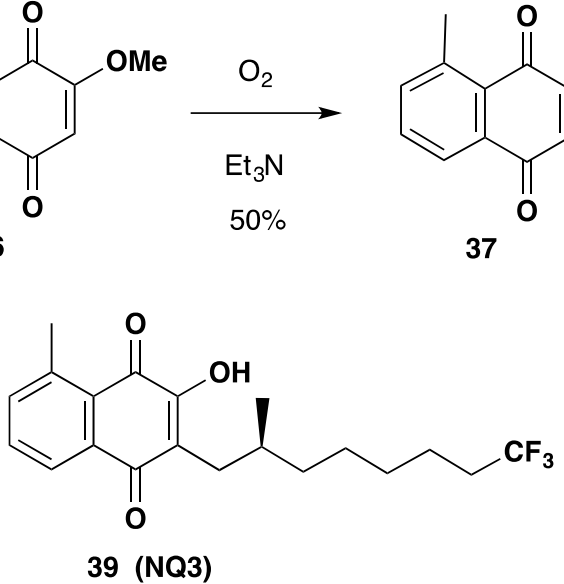

(NQ3)

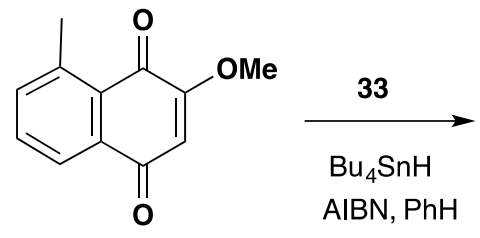

$120^{\circ} \mathrm{C}$ sealed tube<smiles>COC1=C(C[C@H](C)CCCCCC(F)(F)F)C(=O)c2cccc(C)c2C1=O</smiles>

Scheme 5. Synthesis of (S)-3-hydroxy-5-methyl-2-(8,8,8-trifluoro-2-methyloctyl)naphthalene-1,4-dione (39) (NQ3). 
Finally, we synthesized compound 43 (NQ2), the defluorinated version of 39, as shown in Scheme 6. 2-Methoxy-8-methylnaphthalene-1,4-dione (37) was converted into sulfonate $\mathbf{4 1}$ and coupled with iodide 29 as described in Scheme 3 for 5 to give 43 (NQ2) in low yield. As was the case for 39 (NQ3), analogue 43 (NQ2) shows much weaker activity ( $\left(\mathrm{C}_{50} 247 \mathrm{nM}\right)$ than $(S)-5$ against Plasmodium berghei than we expected based on the protein modeling mentioned above. ${ }^{13}$<smiles>COC1=CC(=O)c2cccc(C)c2C1=O</smiles>

37

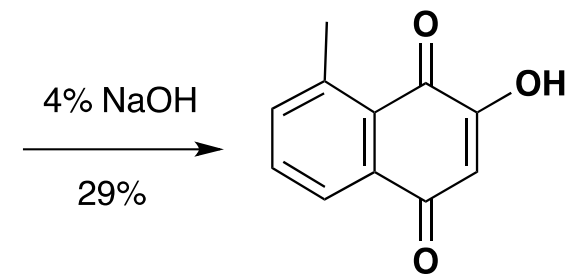

40

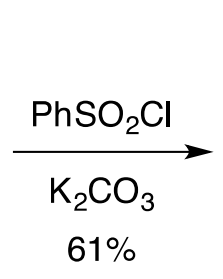

$61 \%$<smiles>Cc1cccc2c1C(=O)C(OS(=O)(=O)O)=CC2=O</smiles>

41
29

$\mathrm{Bu}_{4} \mathrm{SnH}$

AIBN, $\mathrm{PhH}$

$120^{\circ} \mathrm{C}$

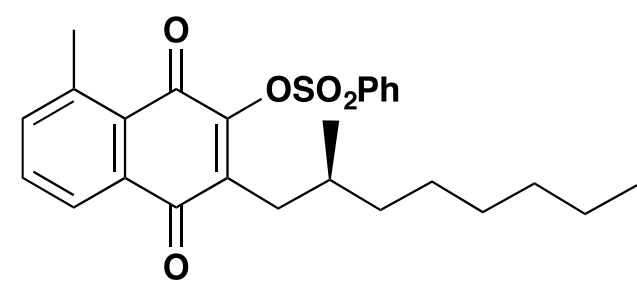

42

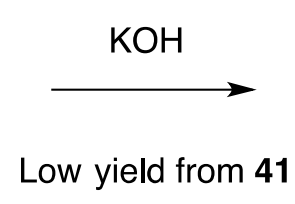

Low yield from 41

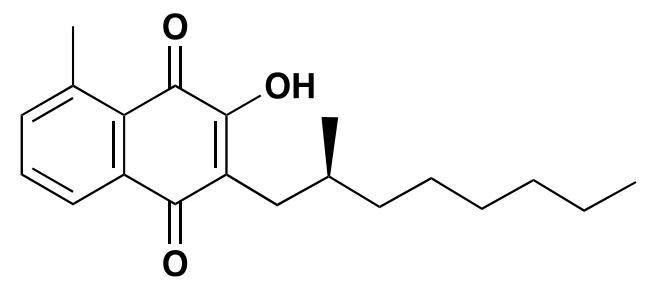

43 (NQ2)

Scheme 6. Synthesis of (S)-3-hydroxy-5-methyl-2-(2-methyloctyl)naphthalene-1,4-dione (43) (NQ2).

\section{Conclusions}

We describe the first synthesis of (S)-2-hydroxy-3-(2-methyloctyl)naphthalene-1,4-dione (S-5), the biologically active enantiomer of the racemate "10576" ("M-285") that Fieser synthesized more than 70 years ago. This compound shows improved activity over atovaquone, which has been used to treat malaria and pneumonia (Pneumocystis) pathogens since the mid 1990s as "Malarone," a combination drug containing atovaquone and proguanil. In fact, the Center for Disease Control (CDC) has recommended Malarone for Americans traveling to nearly all malaria-endemic countries. However, these pathogens soon became resistant to atovaquone and new drugs are greatly needed. ${ }^{30,31}$

By blocking the terminal oxidative metabolism of S-5 with a trifluoromethyl group (7) (NQ1) we have shown that this latter compound is a new lead in the design of improved hydroxy-naphthalene-1,4-dione therapeutics, with 5-6 times greater activity against Plasmodium berghei than S-5. Both 6 and 7 are more active than atovaquone, and $\mathbf{7}$ strongly inhibits atovaquone-resistant Plasmodium falciparum sporozoites. The precise activity of (S)-2-(8-fluoro-2-methyloctyl)-3-hydroxynaphthalene-1,4-dione (6) remains to be established, but it too would be expected to block terminal group metabolism. We have also shown that the presence of an 8-methyl group in these compounds (39 and 43) does not lead to improved activity as our protein modeling seemed to suggest.

In Figure 3, we show some additional non-fluorinated compounds that we have synthesized (unpublished) and their $\mathrm{IC}_{50}$ activity. Activity below $200 \mathrm{nM}$ is considered to be significant. Importantly, the activity of $R$-5 is nearly 30 times less that that of $S-5$ against the yeast $b c 1$ complex. The difference in activity between the two 
epimers of $\mathbf{5}$ is believed to involve different interactions of the 2-methyloctyl side chain with the binding groove of the yeast cytochrome bc1 complex. Whereas both the $S$ and $R$ isomers of $\mathbf{5}$ show a strong hydrophobic interaction with valine-146 in the protein complex, the $S-5$ interaction constrains the rotation of the "loose end" of the side chain in the protein binding groove and allows for stronger binding than does the $R-5$ epimer by nearly a factor of $30 .^{11}$<smiles>CCCCCC[C@H](C)CC1=C(O)C(=O)c2ccccc2C1=O</smiles><smiles>CCCCCCCCCCC1=C(O)C(=O)c2ccccc2C1=O</smiles>

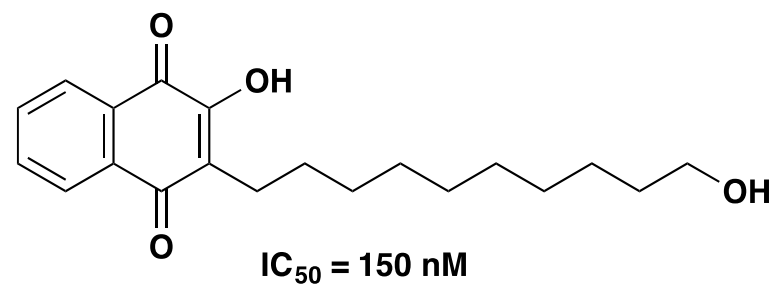<smiles></smiles><smiles>CCCCCCCC1=C(O)C(=O)c2ccccc2C1=O</smiles>

$I_{50}=80 \mathrm{nM}$<smiles>CCCCCCCCCCCCCCCC1=C(O)C(=O)c2ccccc2C1=O</smiles><smiles></smiles><smiles>CC(C)=CCC/C(C)=C/CC1=C(O)C(=O)c2ccccc2C1=O</smiles>

Figure 3. Structures of 2-hydroxynaphthalene-1,4-diones and $I C_{50}(\mathrm{nM})$ against the yeast $b c 1$ complex.

\section{Experimental Section}

General. All reactions were performed under positive nitrogen pressure in oven-dried glassware. Reactions were monitored by thin-layer chromatography $(T L C)$ on silica gel plates $(0.25 \mathrm{~mm})$ and visualized under shortwave UV light at $254 \mathrm{~nm}$ or by staining with $p$-anisaldehyde or $\mathrm{KMnO}_{4}$ and heating. Unless otherwise noted, all organic extracts were washed with brine, dried over $\mathrm{MgSO}_{4}$ and concentrated in vacuo as a standard work-up procedure. Column chromatography was run using silica gel with particle size 40-63 $\mu \mathrm{m}$. Melting points were measured using the Mel Temp apparatus of Laboratory Devices with samples prepared in open capillary tubes. Mass spectra were performed by the SCS Mass Spectrometry lab at the University of Illinois. 
IR spectra were obtained by using a Jasco FT/IR-4100 spectrometer. ${ }^{1} \mathrm{H}$ and ${ }^{13} \mathrm{C} N M R$ spectra were recorded at $600 \mathrm{MHz}$ and $150 \mathrm{MHz}$, respectively, using Bruker Avance III HD 600 spectrometer. Chemical shifts $(\delta)$ were reported in parts per million $(\mathrm{ppm})$ using the residual signal of the solvent as an internal reference $\left(C D C l_{3}, \delta_{H}\right.$ 7.26; $\delta_{\mathrm{C}}$ 77.23). Multiplicities were reported using the following abbreviations: singlet (s), doublet (d), triplet $(\mathrm{t})$, quartet $(\mathrm{q})$, multiplet $(\mathrm{m})$, and broad (br).

(S)-4-Benzyl-3-(8-bromooctanoyl)oxazolidin-2-one (20). To a solution of 8-bromooctanoic acid (8) (4.13 g, $18.5 \mathrm{mmol}$ ) in $\mathrm{CH}_{2} \mathrm{Cl}_{2}(200 \mathrm{~mL})$, oxalyl chloride $(8 \mathrm{~mL}, 93 \mathrm{mmol})$ was added. The reaction mixture was stirred overnight. The crude acyl chloride 19 was concentrated in vacuo and stored under vacuum. In a separate round-bottomed flask, a solution of (S)-4-benzyloxazolidin-2-one (12) (4.26 g, $18.5 \mathrm{mmol})$ and DMAP (0.27 g, $2.2 \mathrm{mmol})$ in $\mathrm{CH}_{2} \mathrm{Cl}_{2}(200 \mathrm{~mL})$ was stirred at $0{ }^{\circ} \mathrm{C}$. Then $\mathrm{Et}_{3} \mathrm{~N}(9.7 \mathrm{~mL}, 69 \mathrm{mmol})$ was added dropwise into the reaction mixture, followed by the above acyl chloride in $\mathrm{CH}_{2} \mathrm{Cl}_{2}(10 \mathrm{~mL})$. The reaction was stirred overnight, and after TLC confirmed completion, the reaction was concentrated in vacuo and covered with EtOAc (100 $\mathrm{mL})$. The solution was extracted with EtOAc, washed with $3 \% \mathrm{HCl}(100 \mathrm{~mL})$, saturated $\mathrm{NaHCO}_{3}(100 \mathrm{~mL})$, and brine $(100 \mathrm{~mL})$, and dried. It was finally concentrated in vacuo, then purified using flash chromatography to give 20 as a thick oil, $5.67 \mathrm{~g}\left(80 \%\right.$ from 8): $[\alpha]_{D}+37^{\circ} ;{ }^{1} \mathrm{H} \mathrm{NMR}\left(\mathrm{CDCl}_{3}\right) \delta 7.20-7.34(5 \mathrm{H}, \mathrm{m}), 4.67(1 \mathrm{H}, \mathrm{m}), 4.15-$ $4.21(2 \mathrm{H}, \mathrm{m}), 3.41(2 \mathrm{H}, \mathrm{t}, J 7 \mathrm{~Hz}), 3.28-3.31(1 \mathrm{H}, \mathrm{dd}, J 13,3 \mathrm{~Hz}), 2.90(1 \mathrm{H}, \mathrm{m}), 2.95(1 \mathrm{H}, \mathrm{m}), 2.75-2.79(1 \mathrm{H}, \mathrm{dd}, J$ 13, $10 \mathrm{~Hz}), 1.87(2 \mathrm{H}, \mathrm{m}, 7 \mathrm{~Hz}), 1.70(2 \mathrm{H}, \mathrm{m}, 6 \mathrm{~Hz}), 1.37-1.46(6 \mathrm{H}, \mathrm{m}) ;{ }^{13} \mathrm{C} \mathrm{NMR}\left(\mathrm{CDCl}_{3}\right) \delta 173.5,153.7,135.5$, 129.6, 129.2, 127.6, 66.4, 55.4, 38.1, 35.7, 34.1, 32.9, 29.1, 28.7, 28.2, 24.3; IR: $v_{\max }\left(\mathrm{cm}^{-1}\right)$ 2930, 1780, 1700, 1390, 1210, 701. Anal. HRMS m/z Calcd for $\mathrm{C}_{18} \mathrm{H}_{25} \mathrm{BrNO}_{3}(\mathrm{M}+\mathrm{H}):$ : 382.1018. Found: 382.1013.

(S)-4-Benzyl-3-((S)-8-bromo-2-methyloctanoyl)oxazolidin-2-one (21). To a solution of NaHMDS (26 mL, 26.3 $\mathrm{mmol})$ in THF $(200 \mathrm{~mL})$ while stirred at $-78{ }^{\circ} \mathrm{C}$, a pre-cooled solution of the oxazolidinone 20 (8.37 g, 21.9 $\mathrm{mmol}$ ) in THF $(50 \mathrm{~mL})$ was added dropwise. After an hour of stirring, methyl iodide $(6.8 \mathrm{~mL}, 110 \mathrm{mmol}) \mathrm{was}$ added dropwise, and the reaction mixture was stirred for $4 \mathrm{~h}$ at the same temperature. Upon completion of the reaction as indicated by $\mathrm{TLC}$, the reaction mixture was quenched with saturated $\mathrm{NH}_{4} \mathrm{Cl}(\mathrm{aq})$. After the solvent was removed in vacuo, the mixture was extracted with $\mathrm{CH}_{2} \mathrm{Cl}_{2}$, washed consecutively with $5 \% \mathrm{KHSO}_{4}$, saturated $\mathrm{Na}_{2} \mathrm{~S}_{2} \mathrm{O}_{3}$, and brine, dried, and concentrated in vacuo. The crude product was purified by flash chromatography using ethyl acetate and hexanes, affording $6.51 \mathrm{~g}(75 \%)$ of 21 as a thick, colorless oil: [ $\alpha]_{D}$ $+33^{\circ} ;{ }^{1} \mathrm{H}$ NMR $\left(\mathrm{CDCl}_{3}\right) \delta$ 7.20-7.33 $(5 \mathrm{H}, \mathrm{m}), 4.68(1 \mathrm{H}, \mathrm{m}), 4.17-4.20(2 \mathrm{H}, \mathrm{m}) ; 3.70(1 \mathrm{H}, \mathrm{m}, J 7 \mathrm{~Hz}), 3.41(2 \mathrm{H}, \mathrm{t}, J$ $6 \mathrm{~Hz}), 3.27(1 \mathrm{H}, \mathrm{dd}, J$ 13, $4 \mathrm{~Hz}), 2.77(1 \mathrm{H}, \mathrm{dd}, 13, J 9 \mathrm{~Hz}), 1.84(2 \mathrm{H}, \mathrm{m}, J 7 \mathrm{~Hz}), 1.75(1 \mathrm{H}, \mathrm{m}, J 6.17 \mathrm{~Hz}), 1.42$ $(3 \mathrm{H}, \mathrm{m}, J 6.17 \mathrm{~Hz}), 1.32(4 \mathrm{H}, \mathrm{m}, J 2.94 \mathrm{~Hz}), 1.21(3 \mathrm{H}, \mathrm{d}, J 6.81 \mathrm{~Hz}) ;{ }^{13} \mathrm{C} \mathrm{NMR}\left(\mathrm{CDCl}_{3}\right) \delta 177.4,153.3,135.5$, 129.7, 129.2, 127.6, 66.2, 55.6, 38.1, 37.9, 34.1, 33.5, 32.9, 29.0, 28.2, 27.3, 17.6; IR: $v_{\max }\left(\mathrm{cm}^{-1}\right) 2930,2360$, 1780, 1700, 1390, 1210. Anal. HRMS m/z Calcd for $\mathrm{C}_{19} \mathrm{H}_{27} \mathrm{BrNO}_{3}(\mathrm{M}+\mathrm{H})^{+}: 396.1174$. Found: 396.1165 .

(S)-8-Bromo-2-methyloctanoic acid (22). To a solution of 21 (0.66 g, $1.67 \mathrm{mmol}$ ) in THF-water (40 mL) in 3:1 ratio stirring at $0{ }^{\circ} \mathrm{C}, \mathrm{H}_{2} \mathrm{O}_{2}(30 \%, 1.6 \mathrm{~mL}, 16 \mathrm{mmol})$ was added. After $10 \mathrm{~min}, \mathrm{LiOH} \cdot \mathrm{H}_{2} \mathrm{O}(0.14 \mathrm{~g}, 3.33 \mathrm{mmol})$ was added. The reaction mixture was stirred for $3 \mathrm{~h}$, then quenched with $\mathrm{Na}_{2} \mathrm{SO}_{3}$. The solution was washed with EtOAc and separated. The aqueous solution was covered with EtOAc and acidified to $\mathrm{pH} 2$ with $5 \% \mathrm{KHSO}_{4}$. The organic layer was extracted with EtOAc, washed with brine, dried, and concentrated in vacuo to give 22 (0.33 $\mathrm{g}, 83 \%)$, as a colorless liquid, which was used in the next step without further purification: $[\alpha]_{\mathrm{D}}+4.4^{\circ} ;{ }^{1} \mathrm{H} \mathrm{NMR}$ $\left(\mathrm{CDCl}_{3}\right) \delta 11.2(1 \mathrm{H}, \mathrm{br} \mathrm{s}), 3.40(2 \mathrm{H}, \mathrm{t}, J 7 \mathrm{~Hz}), 2.47(1 \mathrm{H}, \mathrm{m}, J 7 \mathrm{~Hz}), 1.85(2 \mathrm{H}, \mathrm{m}, J 7 \mathrm{~Hz}), 1.66(1 \mathrm{H}, \mathrm{m}, J 7 \mathrm{~Hz})$, $1.43(3 \mathrm{H}, \mathrm{m}, J 7 \mathrm{~Hz}), 1.33(4 \mathrm{H}, \mathrm{m}, J 5 \mathrm{~Hz}), 1.18(3 \mathrm{H}, \mathrm{d}, J 8 \mathrm{~Hz}) ;{ }^{13} \mathrm{C} \mathrm{NMR}\left(\mathrm{CDCl}_{3}\right) \delta 182.5,39.4,34.1,33.6,32.9$, 28.9, 28.2, 27.2, 17.1; IR: $v_{\max }\left(\mathrm{cm}^{-1}\right)$ 2935, 2858, 1704, 1464, 1241, 941. Anal. HRMS $\mathrm{m} / \mathrm{z}$ Calcd for $\mathrm{C}_{9} \mathrm{H}_{18} \mathrm{BrO}_{2}$ : 237.0490. Found: 237.0489. 
(S)-8-Bromo-2-methyl-1-octanol (23). To a stirred solution of 22 (1.0 eq) in dry ether at $0{ }^{\circ} \mathrm{C}, \mathrm{LiAlH}_{4}(3.0 \mathrm{eq}, 4.0$ $M$ solution in dry ether) was added dropwise. The mixture was stirred overnight. After quenching with water, the mixture was extracted with diethyl ether, washed with brine, dried, and concentrated in vacuo. The crude product 23, as a colorless liquid, was used in the next step without further purification: $[\alpha]_{D}+88^{\circ} ;{ }^{1} \mathrm{H} N M R$ $\left(\mathrm{CDCl}_{3}\right) \delta 3.49-3.52(1 \mathrm{H}, \mathrm{dd}, J 10,6 \mathrm{~Hz}), 3.40-3.44(3 \mathrm{H}, \mathrm{m}), 1.83-1.87(2 \mathrm{H}, \mathrm{m}, \mathrm{J} 7 \mathrm{~Hz}), 1.26-1.45(9 \mathrm{H}, \mathrm{m})$; IR: $v_{\max }\left(\mathrm{cm}^{-1}\right)$ 3340, 2928, 1464, 1260, 1040, 646.

(S)-8-Bromo-2-methyloctanal (24). To a stirred solution of oxalyl chloride $(1.37 \mathrm{~mL}, 16.0 \mathrm{mmol})$ in $5 \mathrm{~mL}$ of $\mathrm{CH}_{2} \mathrm{Cl}_{2}$ at $-78{ }^{\circ} \mathrm{C}$, DMSO $(2.27 \mathrm{~mL}, 32.0 \mathrm{mmol}$ ) was added dropwise. After stirring for $15 \mathrm{~min}$, a solution of 23 (1.19 g, $5.33 \mathrm{mmol})$ in $10 \mathrm{~mL} \mathrm{CH} \mathrm{Cl}_{2}$ and $\mathrm{Et}_{3} \mathrm{~N}(6.69 \mathrm{~mL}, 48.0 \mathrm{mmol})$ were added consecutively. The solution was stirred for 45 min while warming up to room temperature. The solution was quenched with water, extracted with $\mathrm{CH}_{2} \mathrm{Cl}_{2}$, washed with brine, dried, and concentrated in vacuo. The crude product was purified via flash chromatography, affording $1.1 \mathrm{~g}(93 \%)$ of 24 as a colorless liquid, $[\alpha]_{\mathrm{D}}+9^{\circ} ;{ }^{1} \mathrm{H} \mathrm{NMR}\left(\mathrm{CDCl}_{3}\right) \delta 9.61(1 \mathrm{H}$, d, J $2 \mathrm{~Hz}), 3.40(2 \mathrm{H}, \mathrm{t}, J 7 \mathrm{~Hz}), 2.33(1 \mathrm{H}, \mathrm{m}), 1.85(2 \mathrm{H}, \mathrm{m}, J 7 \mathrm{~Hz}), 1.71(1 \mathrm{H}, \mathrm{m}, J 6 \mathrm{~Hz}), 1.33-1.46(7 \mathrm{H}, \mathrm{m}), 1.10$ $(3 \mathrm{H}, \mathrm{d}, J 7 \mathrm{~Hz}) ;{ }^{13} \mathrm{C} \mathrm{NMR}\left(\mathrm{CDCl}_{3}\right) \delta 182.2,161.1,71.2,39.4,35.9,34.1,33.6$ 32.9, 28.9, 28.2, 27.2, 25.3, 20.2, 17.1; IR: $v_{\max }\left(\mathrm{cm}^{-1}\right)$ 2933, 2858, 1703, 1463. Anal. HRMS $\mathrm{m} / z$ Calcd for $\mathrm{C}_{9} \mathrm{H}_{16} \mathrm{BrO}(\mathrm{M}+\mathrm{H})^{+}: 219.0385$. Found: 219.0383.

(S)-2-(8-Bromo-2-methyłoctyl)-3-hydroxynaphthalene-1,4-dione (25). In a round-bottom flask equipped with a stirring bar, aldehyde 24 (2.0 eq), 2-hydroxynaphthalene-1,4-dione (17) (1.0 eq), the' Hantzsch ester (1.0 eq), and $\mathrm{L}$-proline $(0.5 \mathrm{eq})$ were all combined together in $\mathrm{CH}_{2} \mathrm{Cl}_{2}$ and stirred at $\mathrm{rt}$ for $48 \mathrm{~h}$. The reaction mixture was concentrated in vacuo, then purified via flash column chromatography using hexanes and EtOAc to give $\mathbf{2 5}$ (78\%) as a yellow solid: $\operatorname{mp~} 81-82^{\circ} \mathrm{C} ;[\alpha]_{\mathrm{D}}=+0.9^{\circ} ;{ }^{1} \mathrm{H} \mathrm{NMR}\left(\mathrm{CDCl}_{3}\right) \delta 8.07-8.12(2 \mathrm{H}, \mathrm{dd}, \mathrm{J} 7 \mathrm{~Hz}), 7.66-7.76(2 \mathrm{H}$, $\mathrm{dt}, J 8 \mathrm{~Hz}), 7.33(1 \mathrm{H}, \mathrm{s}), 3.39(2 \mathrm{H}, \mathrm{t}, J 7 \mathrm{~Hz}), 2.57-2.61(1 \mathrm{H}, \mathrm{dd}, J 6 \mathrm{~Hz}), 2.42-2.45(1 \mathrm{H}, \mathrm{dd}, J 8 \mathrm{~Hz}), 1.81-1.85(3 \mathrm{H}$, $\mathrm{m}, J 8 \mathrm{~Hz}), 1.29-1.42(8 \mathrm{H}, \mathrm{m}), 0.88(3 \mathrm{H}, \mathrm{d}, J 7 \mathrm{~Hz}) ;{ }^{13} \mathrm{C} \mathrm{NMR}\left(\mathrm{CDCl}_{3}\right) \delta 185.1,181.6,153.7,135.1,133.2,133.1$, 129.7, 127.0, 126.3, 124.2, 37.3, 34.2, 33.0, 32.95, 30.9, 29.1, 28.4, 27.06, 19.9; IR: $v_{\max }\left(\mathrm{cm}^{-1}\right)$ 3350, 2900, 1630, 1600, 1350, 1250, 700. Anal. HRMS m/z Calcd for $\mathrm{C}_{19} \mathrm{H}_{24} \mathrm{BrO}_{3}(\mathrm{M}+\mathrm{H})^{+}$379.0909. Found: 379.0894 .

(S)-2-Hydroxy-3-(8,8,8-trifluoro-2-methyloctyl)naphthalene-1,4-dione (7) (NQ1). Yield 20 mg (4\%); mp 87-89 ${ }^{\circ} \mathrm{C}$; $[\alpha]_{\mathrm{D}} \mathrm{CH}_{2} \mathrm{Cl}_{2}-1.3$ (c= 1); ${ }^{1} \mathrm{H}$ NMR $\left(\mathrm{CDCl}_{3}\right) \delta 8.14-8.09$ (dd, J $\left.8.0 \mathrm{~Hz}, 2 \mathrm{H}, \mathrm{H}-5, \mathrm{H}-8\right), 7.68-7.79(2 \mathrm{H}, \mathrm{H}-6, \mathrm{H}-7)$, 7.79-7.68 (m, 2H, H-6, H-7), $7.30(\mathrm{br}, 1 \mathrm{H}, \mathrm{OH}), 2.43-2.63(\mathrm{~m}, 4 \mathrm{H}), 2.09-2.04\left(\mathrm{~m}, 2 \mathrm{H}, \mathrm{CH}_{2}\right), 1.86(\mathrm{br}, 1 \mathrm{H}, \mathrm{CH})$, 1.36-1.24 (br, $\left.10 \mathrm{H},\left(\mathrm{CH}_{2}\right)_{5}\right) ;{ }^{19} \mathrm{~F} \mathrm{NMR}\left(\mathrm{CDCl}_{3}\right) \delta-66.8(\mathrm{t}, \mathrm{J} 11.8 \mathrm{~Hz}) ;(\mathrm{El}) \mathrm{m} / \mathrm{z} 354(88 \%)(\mathrm{M})^{+}$. Anal. HRMS Calcd for $\mathrm{C}_{19} \mathrm{H}_{21} \mathrm{~F}_{3} \mathrm{O}_{3} 354.1443$. Found: 354.1442 .

(S)-3-Hydroxy-5-methyl-2-(8,8,8-trifluoro-2-methyloctyl)naphthalene-1,4-dione (39) (NQ3). Yield 1 mg (4\%); ${ }^{1} \mathrm{H}$ NMR $\left(\mathrm{CDCl}_{3}\right) \delta 8.19-8.18(\mathrm{~d}, \mathrm{~J} 2 \mathrm{~Hz}, 1 \mathrm{H}, \mathrm{H}-5), 7.64-7.62(2 \mathrm{H}, \mathrm{H}-6, \mathrm{H}-7), 7.57(\mathrm{br}, 1 \mathrm{H}, \mathrm{OH}), 2.93\left(\mathrm{~s}, 3 \mathrm{H}, \mathrm{CH}_{3}\right)$, $2.78\left(\mathrm{~s}, 3 \mathrm{H}, \mathrm{CH}_{3}\right), 2.41-2.58(\mathrm{~m}, 4 \mathrm{H}), 2.11-2.04\left(\mathrm{~m}, 2 \mathrm{H}, \mathrm{CH}_{2}\right), 1.86(\mathrm{br}, 1 \mathrm{H}, \mathrm{CH}), 1.36-1.24\left(\mathrm{br}, 10 \mathrm{H},\left(\mathrm{CH}_{2}\right)_{5}\right) .{ }^{19} \mathrm{~F}$ NMR $\left(\mathrm{CDCl}_{3}\right) \delta-66.8$ (t, J $12 \mathrm{~Hz}$ ). (El) $\mathrm{m} / z 368$ (88\%) $\left(\mathrm{M}^{+} \mathrm{H}^{+}\right.$). Anal. HRMS Calcd for $\mathrm{C}_{20} \mathrm{H}_{23} \mathrm{~F}_{3} \mathrm{O}_{3}: 368.1599$. Found: 368.1604 .

S-2-Hydroxy-3-(2-methyloctyl)-8-methylnaphthalene-1,4-dione (43) (NQ2). Yield $5 \mathrm{mg}(11 \%): \mathrm{mp} 53-55^{\circ} \mathrm{C}$; ${ }^{1} \mathrm{H}$ NMR $\left(\mathrm{CDCl}_{3}\right) \delta 8.19-8.18(\mathrm{~d}, \mathrm{~J} 2 \mathrm{~Hz}, 1 \mathrm{H}, \mathrm{H}-5), 7.64-7.62(2 \mathrm{H}, \mathrm{H}-6, \mathrm{H}-7), 7.57$ (br, 1H, OH), 2.67-2.43 (m, 2H, $\left.\mathrm{CH}_{2}\right), 1.86(\mathrm{br}, 1 \mathrm{H}, \mathrm{CH}), 1.40-1.19\left(\mathrm{br}, 10 \mathrm{H},\left(\mathrm{CH}_{2}\right)_{5}\right), 0.93-0.88\left(\mathrm{~m}, 6 \mathrm{H}, \mathrm{CH}_{3}, \mathrm{CH}_{3}\right) ;(\mathrm{EI}) \mathrm{m} / z$ 314 (82\%); Anal. HRMS Calcd for $\mathrm{C}_{20} \mathrm{H}_{26} \mathrm{O}_{3}$ : 314.1882. Found: 314.1880 . 


\section{Acknowledgements}

We acknowledge and thank Dartmouth College for support of this work, and E.E.K. acknowledges a Zabriskie Fellowship from Dartmouth College. We recognize the late Bernard L. Trumpower for the genesis of this project. He is greatly missed.

\section{References}

1. Honigsbaum, M. The Fever Trail: In Search of the Cure for Malaria, Macmillan, Great Britain, 2001.

2. Breman, J. G. Am. J. Trop. Med. Hyg. 2001, 64, 1.

3. Nixon, G. L.; Moss, D. M.; Shone, A. E.; Lalloo, D. G.; Fisher, N; O’Neill, P. M.; Ward, S. A.; Biagini, G. A. J. Antimicrob. Chemother. 2013, 68, 977.

https://doi.org/10.1093/jac/dks504

4. de Castro, S. L.; Emery, F. S.; da Silva Júnior, E. N. Eur. J. Med. Chem. 2013, 69, 678. https://doi.org/10.1016/i.ejmech.2013.07.057

5. Lopez-Lopez, L. I.; Nery-Flores, S. D.; Silva-Belmares, S. Y.; Saenz-Galindo, A. Rev. Fac. Quím. Farmaceut. 2014, 21, 248.

6. de Carvalho da Silva, F.; Ferreira, V. F. Curr. Org. Synth. 2016, 13, 334. https://doi.org/10.2174/1570179412666150817220343

7. Sánchez-Calvo, J. M.; Barbero, G. R.; Guerrero-Vásquez, G.; Durán, A. G.; Macías, M.; Rodríguez-Iglesias, M. A.; Molinillo, J. M. G.; Macías, F. A. Med. Chem. Res. 2016, 25, 1274. https://doi.org/10.1007/s00044-016-1550-x

8. Novais, J. S.; Moreira, C. S.; Silva, A. C. J. A; Loureiro, R. S.; Figueiredo, A. M. S.; Ferreira, V. F.; Castro, H. C.; da Rocha, D. R. Microb. Pathogen. 2018, 118, 105. https://doi.org/10.1016/i.micpath.2018.03.024

9. da Silva Júnior, E. N.; Jardim, G. A. M.; Jacob, C.; Dhawa, U.; Ackermann, L.; de Castro, S. L. Eur. J. Med. Chem. 2019, 179, 863. https://doi.org/10.1016/i.ejmech.2019.06.056

10. Olawode, E. O.; Tandlich, R.; Prinsloo, E.; Isaacs, M.; Hoppe, H.; Seldon, R.; Warner, D. F.; Steenkamp, V.; Kaye, P. T Bioorg. Med. Chem. Lett. 2019, 29, 1572. https://doi.org/10.1016/i.bmcl.2019.05.001

11. Kessl, J. J.; Moskalev, N. V.; Gribble, G. W.; Nasr, M.; Meshnick, S. R.; Trumpower, B. L. Biochem. Biophys. Acta 2007, 1767, 319. https://doi.org/10.1016/j.bbabio.2007.02.014

12. Hughes, L. M.; Covian, R.; Gribble, G. W.; Trumpower, B. L. Biochim. Biophys. Acta 2010, 1797, 38. https://doi.org/10.1016/i.bbabio.2009.07.010

13. Hughes, L. M.; Lanteri, C. A.; O’Neil, M. T.; Johnson, J. D.; Gribble, G. W.; Trumpower, B. L. Mol. Biochem. Parasitol. 2011, 177, 12. https://doi.org/10.1016/i.molbiopara.2011.01.002

14. Trumpower, B. L. Microbiol. Rev. 1990, 54, 101. https://doi.org/10.1128/MMBR.54.2.101-129.1990 
15. Fieser, L. F.; Berliner, E; Bondhus, F. J.; Chang, F. C.; Dauben, W. G.; Ettlinger, M. G.; Fawaz, G.; Fields, M.; Heidelberger, C.; Heymann, H.; Vaughan, W. R.; Wilson, A. G.; Wilson, E.; Wu, M.; Leffler, M. T.; Hamlin, K. E.; Matson, E. J.; Moore, E. E.; Moore, M. B.; Zaugg, H. E. J. Amer. Chem. Soc. 1948, 79, 3174. https://doi.org/10.1021/ja01190a004

16. Fieser, L. F.; Chang, F. C.; Dauben, W. G.; Heidelberger, C.; Heymann, H.; Seligman, A. M. J. Pharmacol. Exp. Therapeut. 1948, 94, 85.

17. Kim, E. E.; Onyango, E. O.; Fu, L.; Gribble, G. W. Tetrahedron Lett. 2015, 56, 6707. ttps://doi.org/10.1016/i.tetlet.2015.10.054

18. Buckle, F. J.; Pattison, F. L. M.; Saunders, B. C. J. Chem. Soc. 1949, 1471. https://doi.org/10.1039/JR9490001471

19. Kim, E. E.; Onyango, E. O.; Pace, J. R.; Abbot, T. M.; Fu, L.; Gribble, G. W. Tetrahedron Lett. 2016, $57,864$. https://doi.org/10.1016/j.tetlet.2016.01.036

20. Evans, D. A.; Ennis, M. D.; Mathre, D. J. J. Am. Chem. Soc. 1982, 104, 1737. https://doi.org/10.1021/ja00370a050

21. Wipf, P.; Kim, Y.; Fritch, P. C. J. Org. Chem. 1993, 58, 7195. https://doi.org/10.1021/jo00077a050

22. Chen, H.; Feng, Y.; Xu, Z.; Ye, T. Tetrahedron 2005, 61, 11132. https://doi.org/10.1016/i.tet.2005.09.040

23. Shirai, Y.; Seki, M.; Mori, K. Eur. J. Org. Chem. 1999, 3139. https://doi.org/10.1002/(SICI)1099-0690(199911)1999:11<3139::AID-EJOC3139>3.0.CO;2-8

24. Hasek, W. R. Org. Syn. 1961, 41, 104. https://doi.org/10.15227/orgsyn.041.0104

25. Guindon, Y.; Delorme, D.; Lau, C. K.; Zamboni, R. J. Org. Chem. 1988, 53, 267. https://doi.org/10.1021/jo00237a008

26. Adler, E.; Magnusson, R. Acta Chem. Scand. 1959, 13, 505. https://doi.org/10.3891/acta.chem.scand.13-0505

27. Parker, K. A.; Spero, D. M.; Koziaki, K. A. J. Org. Chem. 1987, 52, 183. https://doi.org/10.1021/jo00378a005

28. Bohlmann, F; Mathar W.; Schwarz, H. Chem. Ber. 1977, 110, 2028. https://doi.org/10.1002/cber.19771100603

29. Guzikowski, A. P.; Cai, S. X.; Espitia, S. A.; Hawkinson, J. E.; Huettner, J. E.; Nogales, D. F.; Tran, M.; Woodward, R. M.; Weber, E.; Keana, J. F. J. Med. Chem. 1996, 39, 4643. https://doi.org/10.1021/jm960479z

30. Srivastava, J. K.; Morrisey, J. M.; Darrouzet, E.; Daldal, F.; Vaidya, A. B. Mol. Microbiol. 1999, $33,704$. https://doi.org/10.1046/i.1365-2958.1999.01515.x

31. Sutherland, C. J.; Laundy, M.; Price, N.; Burke, M.; Fivelman, Q. L.; Pasvol, G.; Klein, J. L.; Chiodini, P. L. Malar. J. 2008, 7, 240. https://doi.org/10.1186/1475-2875-7-240 